\title{
Problems of Islamic Law in Indonesia
}

\author{
by : Yudlan Wahyudl
}

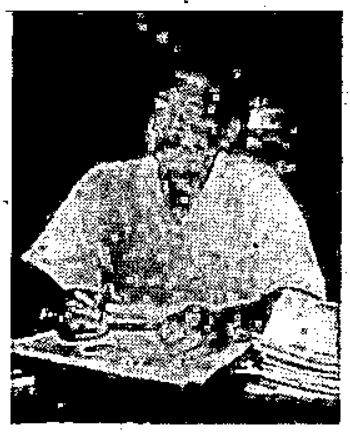

Yudlan W. Asmin, lahir di Balik Papan 17 April 1960, AlumniFakultas Syariah IAIN Sunan Kalijaga Yogyakarta (1982) dan Fakultas Filsafat UGM (1986): Setahun setelah diwisuda terpilih untuk mengikuti Program Pembibitan calon Dosen IAIN se-Indonesia. Gelar MA diperoleh dari The institute of Islamic Studies, Mc Gill University, Kanada (1993). Selain sebagai tenaga pengajar Filsafat Hukum Islam di Fakultas Syariah IAIN aktifjuga menterjemahkan BukuBahasa Arab dan Inggris ke dalam Bahasa Indones̉ia.

\section{Introduction}

The history of Islamic law (figh) in Indonesia has been neglected by Indonesian scholars. Indeed, among older scholars tasawwuf received attention, while in the recent period studies of the Qur'an and Hadith have been'prominent, but few studies of $f i g h$ have appeared. The attention paid to it has always been much less than, for example, the history of Islamic political movement of Indonesia. ${ }^{1}$ Indonesian scholars as such consider the history of figh

1.There are a great number of books that deal with the Islamic political movement in Indonesia. Some of twentieth century works by Indonesian - scholars are : (1) Sartono Kartodirdjo, Protest Movement in Rural Java : A Study of Agrarian Unrest in the Nineteenth and Early Twentieth Centuries, (Singapura:Oxford University Press, 1973).

(2) Ridwan Saidi, Pemuda Islam dalam Dinamika PolitikBangsa 1925-1984 (Jakarta: Rajawali; 1984). (3) Ahmad Syafii Maarif, Islam dan Masaldh
Kenegaraan Studi tentang Percaiuran dalam Konstiluante (Jakarta : LP3ES, 1985). '(4) Ahmad Syafii Maarif, Islam dan Politik di Indonesia pada Masa Demokrasi Terpimpin (1959-1965) (Yogyakarta : Sunan Kalijaga Press, 1988). (5) M.A. Gani, Cita Dasar dan Pola Perjuangan Syarikat Islam (Jakárta' : Bulan Bintang, 1984). (6)'Deliar Noer, The Modernist Movement in Indonesia 1900 1942 (Singapore-Kuala Lumpur: Oxford University Perss, 1973). (7) Deliar Noer, Partai Islam di Pentas Nasional (Jakarta : Grafitipers, 1987). (8) Endang Shaifuddin Anstiari, The Jakarta Charter 1945': The Struggle for an Islamic Constitution in Indonesia (Kuala Lumpur: Mưslim Youth Movement of Malaysia, 1970). (9) Ibrahim Alfian, Perang di.Jalan Allah (Jakarta : Pustaka Sinar Harapan, 1987). To these above can be added numerous works by nonIndonesia are difficult to find. Wan Ahmad Saghir Abdullah, Perkembangan llmu Figh dan Tokohtokohnya di Asia Tenggara (1) (Solo : CV. Ramadhani, 1985) and $\dot{S}$ amsul Wahidin and Abdurrahman, Perkembangan Ringḱas Hukum Islam di Indonesia (Jakarta : Akademika Pressindo, 1984) are the only two examples that can be mentioned here. 
as not important, ${ }^{2}$ However, perhaps these scholars forget that the steps of Islamic political movement always relate to Islamic law; they cannot be separated one from another, because the latter endorses the former. It is thelack of attention thatpresents further consideration of Islamic law that has hindered Indonesian Muslims from advancing in their attempts to make Islanic relevant to the Indonesian setting.

There are, at least, three problems which Islamic law has always faced since the beginning of Islamic law history in Indonesia. The problems, which will bé discussed below respectively, are the lack of intellectual interest, the inevitable, conflict involved in opposing the political power or govemment, and tensions occasioned by local practices $(a d a t)$. These three problems have always occurred at the same time and supported each other in challenging Islamic law: Islamic law in Indonesia is confronted with powcrful rival' forces.

\section{The Lack of Intellectual Interest.}

Islamic law, which can nevęr be separated from Muslims wherever they live because, it regulates all aspects of their lives, ${ }^{3}$ came to Indonesia, therefore, at the time Muslims first arrived in Indoncisa. ${ }^{4}$ It has always had an important position in Indonesia for Muslim peoples. The intellectual level of Islamic law which was brought to Indonesia was the taqlid (imitative) standard, because when Islam came to Indonesia it was in the taqlid period of Islamic law. ${ }^{6}$ It is better to discuss the following three aspects : the lack of writing, usage of poor references, and lack of regeneration. The accumulative effect of these is that Islamic law has had no intellectual foundation in Indonesia.

The decline of writing in Islamic science as'a whole crept into the field of Islamic law. When Islam came to Indonesia, ${ }^{7}$ figh had not long been in ijtihad period. It is, therefore, understandable that over more than four hundred years Islam in Indonesia' only very few of Islámic law books were written by Indonesian Muslims. One of them is, Sirat al-Mustaqim by Nur.,

2. The Tarikh Tashri, (history of Islamic law developinent), deal with the history of Islamic law as a whole, focused only on the classical and medieval history of Islam and hence does not discuss the history of Islainic law in Indonesia. There is, indeed, Sejarah Peradilan Islam (A History of Islamic Court in Indonesia) another subject in Shari'ah (Islamic Law) Faculty at IAIN. The latter, however, does not discuss the history of Islanic law. It focuses only on the political struggles of law between Islamic law and the Dutch adıninistration in Indonesia.

3. Ismail Suny, "Islam as A System of Law in Indonesia", in Pembaharuan Hukum Islam di Indonesia in Memorian Prof. Mr. Dr. Hazairin, (Jakarta : Penerbit Universitas Indonesia, 1981), 17; Maarif, Islamdan Politik diIndonesiapada MasaDemokrasi Terpimpin, (Yogyakarta_: Sunan Kalijaga Press, 1988), 14; and M.B. Hooker, "Muhammadan Law and Islaunic Law", in Hooker, ed., Islam in SouthEast Asia (Leiden : E.J. Brill, 1983), 164.'

4. Ahmad Azhar Basyir, "Posisi Hukim Islam dalain Pembinaan Hukum Nasional", in Media Dakwah no. 119 Juınadil Akhir 1411/ J anuari 1991, 49.

5. J.C.T: Simorangkir and Woerjono Sastropranoto, Peladjaran Hukum Indonesia, (Jakarta : Gunung Aguing, 1958), 102.

6. Abul Rahlman Haji Ảbduliah, Penikiran Islum di Nusantara: Sejarah dan Perkembangannya Hingga Abadke-19, (Kuala Lumpur: Dewan Bahasa, 1990), 42 and 129-131.

7. The advent of Islam in Indonesia, indeed, is always an interesting topic to discuss. See, for example, Abdullah, ibid, 30-93. 
al-din al-Raniri, which deals with pure worship (ibadah khusus), the rules of prayer, alms-giving and the polgrimage. This book: is considered as the first book written in Nusantara. ${ }^{8}$ Nur al-Din bom in Ranir (Rander) near from Surat in Gujarat(India), and died in September 21, 1658 in India ${ }^{9}$ is representative of Indonesian immigrants who wrote in Indonesia. The second is Mir'a al-Tullab dealing with marriage, $m u^{\prime} a m a l a h$ (human relationships), and inheritance by 'Abd al-Ra'uf Fansuri, as a representative Indoneisan muslim natives who wrote in Indonesia. The third example is Nihayaal-Zain,Sulamal-Munaja, Bahjat al-Wasa'il, Fath al-Mujib, Mirqa Su'udalTasdiq, Kashif al-Shaja' 'Uqud al-Lujain, fi Bayan Huquq al-Zawjain all of which refer to Shafi'ite. ${ }^{10} \mathrm{He}$ is a representative of Indonesian Muslims who wrote abroad.

These figh books of Indonesian Muslim writers are classified as taqlid (imitative) books because they use, as their sources, the taqlid books. The primary sources of the Sirat al-Mustaqim of Nur alDin al-Raniri are Minhaj al-Talibin by Nawawi, Minhaj al-Tullab, and Fath alWahhab by Zakariya al-Ansari,Mukhtasar alFatawa by Ibn Hajaral-Haytami, U' $m a d a$ al-Salikwa'Uddaal-Nasikby Shihabal-Din Ahmad Ibn Lu'lu, al-Naqib and Anwar $l i$ 'Amal al-Barara by Ardabti. The Mir'a al- Tullab by 'Abd al-Rauf Fansuri uses Tuhfa al Tullab of Ibn Hajar al-Haytami and Nihaya al-Muhtaj of Shams al-Din al=: Ramli. ${ }^{11}$ All of Nawawi's figh works, as have been stated earlier, belong to Shafi'ite school; they comment on and summarize other works ${ }^{12}$ that indicate they come under the classification of taqlid books because of the adherence to some madhhaborschool of Islamic law. ${ }^{13}$ The intellectual foundations of Islamic law in Indonesia were weak.

The brittleness of intellectual foundations of Islamic law in Indonesia hás not always been aggravated by a lack of good regeneration. This unfortunate condition can be seen from the teaching of Islamic law. In order to understand Islamic law properly, one must know Arabic well because the primary sources are written in Arabic. Until the independence of Indonesia from the Dutch the only instituion which fortified Islamic law and taught it in Arabic

8. Abdullah, Pemikiran Umat Islam, 127. It implies that after coming of Islam in Indonesia, it took more than three hundred years to produce a fi $h$ book written by an Indonesian Muslim, and can be stated that al-Raniri was the father of Islamic law in Indonesia.

9. Ahmad Daudy, "Tinjauan atas "Fath alMubin"karya Syaikh Nuruddin ar-Raniri", in Warisan Intellektual Islam Indonesia. Telaah atas Karyakarya Klasik, ed. Ahmad Rifa'i Hasan (Bandung : Mizan, 1990), 22.

10.DidiñHafiduddin, "Tinjauan atas "Tafsir al-Munir" Karya Imam Muhammad Nawawi Tanara", in Warisan Intellektual, ed. Ahmad Rifa'i Hasan, 4244.

: 11. Abdullah, Pemikiran Unat Islam di Nusantara, 139-140.

12. Hafiduddin, "Tinjauan atas Tafsir alMunir, in Warisan Intellektual, ed. Ahmad Rifa'i Hasan, 442-44.

13.MuhammadMustafaShalabi, al-Madkhal bi al-Figh Islami wa Qawaid al-Milkiyyat wa alUqud fih, (Cairo: Dar al-Ta'lif, 1960), 74. 
was pesantren. ${ }^{14}$ The merit of pesantren has been to taken over by some Islamic universities since' independence. The alumni of pesantren are, however, always an asset of improvenient of Islamic law in Indonesia when they are given opportunity to continue their study; the pesantren allows this at the middle level ${ }^{15}$ except for takhassus or specialization. ${ }^{16}$.

The main purposes of pesantren in terms of Islamic law are to understand it from Arabic texts, to practice it in everyday life, and to propagate (mendakwahkan) it to society. ${ }^{17}$ It is therefore understandable that they do not concentrate on writing processes in order to produce figh books. Some kyais (usually the pesantren leaders), indeed, translated and commented on some Arabic books. But the famous figh books used to teach the santris (students of pesantren) are Fathal-QaribSharhMatanTaqrib ${ }^{18}$ by Ibn Qasim.al-Ghazi (1512 M), Fath al-Mu'in Sharh Qurra al-'Ain by Zain al-Din alMalibari (1.574M), Minhajal-Talibin by alNawawi(1277M), Hashiyya Fathal-Qarib by Ibrahimal-Bajuri (1891 M), al-lqna' by Sharbini (1569. M), Fath al-Wahhab and Tuhfa by Ibn Hajar (189! M), and Nihaya by al-Ramli $(1550 \mathrm{M}) .{ }^{19}$ Seen from the classification, as stated earlier, these books belong to the taqlid level. They are also out of date and hence did not anticipate the changes which have occurred.

The weakness of regcneration of . Islamic law in Indonesia took place over a. very long time. Indications that this problem is being overcome can be seen in the 1980 's when the post graduate faculty ( $\$ 2$ and S3) of IAIN (the Institue of Islamic Studies) opened, specifically in both IAIN Sunan Kalijaga and IAIN'Syarif
Hidayatullah Jakarta. It gives hope, even thought it is still just a foundation. At current rates of education and intellectual development it can be estimated that two hundred years will be needed to begin serious production of figh studies sophisticated enough to consider as not being at the taqlid level. Considering the four basic weaknesses, according to Mukti Ali, ${ }^{20}$ that is to say : lack of scientific books, lack of sčientific research, lack of academic discussion, and poor understanding of foreign

14. See, for inștance, Simuh, "Aspek Mistik Islam Kejawen dalain "Wirid Hidayä Jati", in Warisan Intellektual Islam Indonesia : Telaah atas Karya-karya Klasik, ed. Ahmad Rifa'i Hasan (Bandung.: Mizan, 1987), 62; M. Habib Hirzin, "Agamadan Ilmu dalam Pesantren", in Pesantren dan Pembaharuan, ed. M. Dawam Rahardjo (Bandung : Mizan, 1988), 86 and 94; and A. Mukti Ali, Beberapa Persoalan Agama Dewasa ini (Jakarta : Rajawali, 1987), 20. Even the latter says that "madrasah" (religious school) in pondok pesantren is the best Islamic system of education and learning in Indonesia". It is very natural that he gives such as a sympathic opinion, because he was graduate from pesantren -- that is to say : Pesantren Tremas. It is, however, interesting to note that the period when pesantren was first established in Indonesia is still debatable. school.

15. It is in the same level as senior high

16. M. HabibHirzin; "Agama dan Iliñu dalam. Pesantren", in Pesantren dan Pembaharuan.

17. Zamakhsjari Dhofier, "Santri-Abangan Kehidupan Orang Jawa : Teropong dari Pesantren", in Agama dan Tantangan Zamaan, (Jakarta : LP3ES, 1985), 192.

18. Deliar Noer, Gerakan Modern Islam : 1900-1942, (Jakarta : LP3ES, 1985), 53.

19. Ibid, 88.

20. Mukti Ali, Persoalan Agama, (Jakarta : Rajawali, 1987), 92 and 193. 
languages (especially Arabic and English) the building of intellectual capacity for $f i q h$ in Indonesia will need a long time.

The weakness of documentation is another negative aspect of Islamic law in Indonesia. ${ }^{21}$ Indeed, many Muslim works are documented in Western libraries, and Western scholars discovered a great number of the lost Muslim works. ${ }^{22}$ Many Indonesian Muslim works, including $f i g h$, remain in name only. They exist only in a discussion or in a book report, but not in reality. ${ }^{23}$ Futhermore, some 'Indonesian Muslims bumed books that they did not agree with. For example, a number of Shams al-Din and Hamzah's books were bumed in the yard of the mosque Bait al Rahman in Aceh.24 In addition, the principle that "al"ilmfi al-sudur la fi al-sutur" (knowledge is in the heart not in paper), even though it has saved the Qur'an and Hadith, is one of the factors that weakened the documentation system, because when an expert dies, the knowledge in his heart will be lost.25 Therefore written documentation is needed to save Islamic law books in Indonesia. ${ }^{26}$

It is clear that Islamic Law came to Indonesian when it was not in ijtihadperiod. Furthermore, Indonesian Muslims adhered strictly to a certain madhhab -- i.e : the Shafi'ite--in which succeeding generations of legal scholars were educated and which became a barrier to new ideas in later times. It became clear that the problems could not be solved just by following bindly a certain madhhab.

21. Islamic aspect in Indonesia as a whole is poorly documented. M.C. Ricklefs, A History of Modern Indonesia, (Bloornington : Indiana University Press, 1981), 29.
22. Sambutan Dr. Harun Nasution in Gustave E. von Grunebaum ed., Islam Kesatuan dalam Keberagamaan '(Jakarta : Yayasan Obor, 1983) quoted in Ahmad Rifai Hasan, "Warisan Intellektual Islam dan Perkembangan Wawasan Masa Depan : Sebuah Pengantar"; In Warisan Intëllektual Islam, (Bandung : Mizan, 1987), 11.

23. This can be seen in the 'experts' disagreement regarding an 'alim's works. For instance, there are three different opinions about Nawawi's works. According to Nurcholish Madjid, Nawawi wrote approximately one hundred books. See Hasan "Warisan Inicllektual, 16. On the other hand, Hafiduddin says that "his (Nawawi) works number 115 or, according to another version, 99 books". Hafiduddin. "Tinjauan 'atas "Tafsir al-Munir", in ibid., 42. Another example can be seen in counting al-Palimbani's works. According to R.O. Winstedt, he wrote only two books: Hidaya al-Salikin and Sair al-Salikin, which respectively are the translation of al-Ghazali's Bidaya al-Hidaya and Lubab Ihya'Ulum al-Din. Uthman el-Muhammadi and G.W.J.Drewes, however, say that al-Palimbani wrote sevenn books :Hidaya al-Salikin, Sair al-Salikin, Zahra al-Murid fi Bayan Kalima al-Tauhid, Tuhfa al-Raghibin fi Bayan Haqiqa Imam al-Mu'minin, Nasiha alMuslimin wa Tazkira al-Mukminin fi Faraid alJihad fi Sabil Allah, 'Urwa al-Wusqa wa Silsila 'Uli al-Itiqa, and Ratib'Abd al-Samad al-Palimbani.In addition, al-Palimbani himself still mentions one more book : Zad al-Muttaqin fi Taulid Rabb alAlamin. See M. Chatib Quzwin. "Syeikh 'Abd alSamad al-Palimbani : Suatu Studi Mengenai Perkembangan Islam di Palembang dalam Abad ke18 Masehi", in Masuk dan Berkembangnya Islam di Sumatera Selatan, ed. K.H.O. Gadjahnata and Sri Edi Swasono, (Jakarta : UIP, 1986), 184.

24. Daudy, "Ar-Raniry" in Warisan Intellekual Islam, 22; and Departemen Agama RI, Ensiklopedi Islam, ed. Harun Nasution et. al., (Jakarta : Departemen Agama RI; 1987/1988), 841.

25. Hirzin, "Agama dan Ilmu", in Pesantren dan Pembaharuan, 87.

26. It seems that Yayasan Masagung's effort to write a documentation, Buku Islam Sejak Tahun 1945 (Jakarta : Pusat Informasi Islam, 1985), is very inportant seen from this aspect. 
The Inevitable Conflict Involved in Opposing the Political Power or Goverment.

Colliding with political authority is no stranger for Islamic law wherever it has existed. Willing to establish Shari'ah in every day life in a state, even though it is a relization of iman (faith) sometime causes tensions between Muslims and their govermments. Islamic law in Indonesia has also oftencame into contact with the government. in, however, different levels. This 'section will try to explain four areas of government which Islamic law faced -- i.e. : under the Islamic kingdom, under the Dutch, under the Japanese, and under the Indonesian republic. The fate of Islamic law has been up and down in Indonesian history.

In the Kingdom of Aceh Dar alSalam, Islamic law was once in opposition, to the Kingdom's interests. The succession. as the most important aspect in herediatary power, also happened in Aceh Daral-Salam. Sultan Iskandarsani died in 1661, and he had no a successor. Indeed, he had a son, Panglima Polim, who had no right to be the Sultan, because he was the son of a concubine of the Sultan. Polim realized this position, particularly since the Sultan had bequeathed him the task of being the inaugurator of the sultan not as the Sultan himself. ${ }^{27}$ Polim obeyed the Sultan, in installing Princess Safiatuddin, his daughter, as the Queen. It, of course; aroused an opposition from the 'ulama', because, in their opinion based on a hadish, a woman cannot be the ruler of a Muslim community. ${ }^{28} \mathrm{~A}$ serious conflicthappened between the palace with Polim as the leader and Islamic law which as maintained by the 'ulama'. Both sides tried to use Islamic law to reinforce their legitimacy.
It seems that Polim, who was the power behind the Queen, used the authority of ' other 'ulama'. Shaikh al-Islam Nur al-Dim al-Raniri and 'Abd al-Ra'uf Fansuri gave the fatwa that a woman and a man are equal. ${ }^{29} \mathrm{It}$ is clear that even though under the Muslim ruler, Islamic was not free from difficulties. .

The most bitter struggles between Islamic law and a government in Indonesia took place in the reign of the Dutch. This conflict was always intense. Perhaps it was because of the fact that the Dutch were foreigners who had colonized Indonesia. The problem here was not to legitimate a ruler's interest such as during the Islamic Kingdom, but was, in reality, a struggle between life and death. The Dutch wanted to weaken Islamic law in Indonesia.

The Islamic religious court (peradilan agama) existed since the very beginning of Islam in Indonesia.30 Realizing its function, the Dutch tried to weaken it in taking the following steps : in 1820 Dutch had started to limit its function, issuing Regenten Instructie (Instruksi kepada para Bupati). They reorganize the Islamic courts through a decision in the Staadblad 1882 No. 152. However, they neither provided allowances for the employees nor gave them the same status as other courts. ${ }^{31}$ The Dutch, even-

27. Abdullah, Pemikiran Umat Islam di Nusantara, 129.

28. Ibid.

29. Ibid. See also Departemen Agama RI. Ensiklopedi Islam, ed. Harun Nasution et al. (Jakarta : Departemen Agama, 1988), 2 : 841.

30. Zain Ahmad Noeh and Abdul Basit Adnan, Sejarah Singkat Peradilan Agama Islam di Indonesia (Surabaya : Bina Ilmu, 1983), 29.

31. Ibid. 
tually, limited its competency to ecamining marriage, divorce, and reconciliation (ruju') cases only through enactin Staadblad 1931 No. 53, which continued up to $1988,{ }^{32}$

In addition, the Ducth tried the upside-down reception in comlexu theory that applied since 1800 and was supported by many Dutch lawyers such as Christian van den Berg. By reception in comlexu they meant that Islamic law applied to Indonesian Muslims. In order to abolish this theory, the Dutch, who were wupported byy some scholars such as Cristioan Snouck Hurgronje, introduced the reception theory. it was customary law (hukum adat) applied in Indonesia. Eventually, the Dutch changed the matters of 75 and 78 of Reglement op het belied der regeering ban Nederlandsch Indie, in a gradual and subtle way so as to reduce the benefit to Indonesian Muslims. They weakened these two matters by enacting the Nederland Staadblad of $1906: 364$ (December 31, 1906) or the Nederland Indie's Staadblad of 1907 No: 204. On June 6, 1919 R.R. was changed again from applying to giving attention to Islamic law. ${ }^{33}$.

On March 8, 1942 the Dutch surrended to Japanese occupation. This opportunity was not wasted by the Japanese. They tried to persuade Indonesian Muslims to help them militarily against the allied forces. In this difficult situation, the Japanese only altered Dutch laws that were not contrary to their interests; ${ }^{34}$ therefore they changed Peradilan Agama (Islamic Religious Court) with Sooryo Hoin. ${ }^{35}$ it implied that there were barriers in which Islamic law was to operate; because both the Dutch and the Japanese were the same in this regard. However, the Japanese controlled
Indonesia only up to August 18, 1945 and afterwards Islamic law entered a new cra.

The struggle between Islamic law and the Ducth political power reached its peak when Indonesia proclaimed fis independence on August 17, 1945. It meant, among others, that the former wins. Indecd, the Preface (Penbukaan) and clause 29 of. the Constitution of Indonesian Republic 1945 (Undang-Undang Dasar'1945) gave a proper position to Islamic law..$^{36}$ Indonesian scholars süch as Hazairin, ${ }^{37}$ Mahadi, ${ }^{38}$ and Ahmad Azhar Basyir ${ }^{39}$ say that the reception theory automatically does not apply, bccause of this Constitution; to Indonesia anymore. They clarify it, because. the reception theory was a Dutch tool deislamize Indonesian Muslim's attachment to Islamic law..$^{40}$

\section{Ibid, 35.}

33. Sajuti Thalib, "Reception in Complexu, Theori Receptie A Contrario", in Pembaharuan Hukum Islam di Indonesia in Memoricm Prof. Mr. Dr. Hazairin, (Jakarta : UI-Press, 1981), 44045.

- 34. M.C. Ricklefs, A. History, 189. lam, 21.

35. Noeh and Adnan, Pcradilan Agama Is-

36. Fathurrahman Jamil, "Upaya Pembaharuan Hukum Islam diIndonesia", in Mimbar Agama \& Budaya, 6 (Desember, 1984), 19.

37. Muhammad Daud Ali, "The Position of Islamic Law in the Indonesian Legal System", in Islam and Society in Southeast Asia ed. Taufik Abdullah (Kuala Lumpur : Institute of Southeast Asian Studies, 1986), 203.

38. Ibid.

39. Ahmad Azhar Basyir, "Posisi Hukum Islam, in Media Dakwah", 50.

40. M. Rusaini Rusin, "Hukum Islann dalam Tata Hukum Indonesia", in Studia Islanica, 8 (JuliSeptember, 1987), 37. 
It should be remembered, however, that Indonesia is not an Islamic state. Islamic law, therefore, cannot be applied in all aspects in this country. One of the challanges that Islarnic law is pacing is $S D S B$ or Sumbangan Dana SosialBerhadiah (Social Donation with Prize) that once involved one of the Chaimmen of the Council of Indonesian Ulama when the $S D S B$ 's name was PORKAS. Muslim,scholars considered it as gambling, which is forbidden by Islam. Thercfore, they asked the government to abrogate Undang-Undang No. 22 Tahun 1954 (Constitution No. 22 Year 1954) which, according to some people, endorses the application of $S D S B .{ }^{41}$ Given popular support for the lottery-type operation and government willingness to countenance it islamic law may have to face SDSB forever. $^{42}$

\section{The Tensions Occasioned by Local Practices}

Indonesia had received the influences of a great number of relitions when Islam was introduced. Indonesia has had its owh culture. ${ }^{43}$ Federspiel says that, in terms of legal system: : It appears that adat law existed in the area long before the arrival of either Islam or Hinduism, and has been successful in maintaining itself despite the influence of these religions". ${ }^{44}$ The recognition of adat (customary) law as a legal system, however, was only formally given at the beginning of the twentieth century. ${ }^{45}$ The tensions between Islamic law and local practices : adat and adat law, will be discussed below.

- Islamiclaw sat side by side with adat for a period of time and in certain locales in the Indonesian archipelago. However, there were important incidents of conflict. In Minangkabau, prior to the arrival of the Dutch, Islamic law collided with local practices. ${ }^{46}$ The gambling and cock fighting were in the blood of the local people and were the principal sport of the king's nephews and the penghulu (village chief) and were the principal activity at every adat party. To the purpose of this party, every negeri (village) had to provide an arena. If a village did have not an arena it did not qualify. ${ }^{47}$

When someone died, the society would come together on the first, the seventh, the fortieth one, and the one thousandth night in his/her house. They usually gambled, and drank alcohol. It seemed that they were not sad, even though they had lost a member of their society. Both 'gambling and drinking traditions are forbidden by

41.Suara Masjid, 204 (Shafar-Rabi'ul Awal $1412 \mathrm{H} /$ Septèmber 1991), 7-14.

、 42. SDSB is snaring the Nahdlatul Ulama. See Tempo no.38 tahun XXI-16 Nopember 1991,21.

43. Mochtar Lubis, Indonesia Land Under thic Rainbow (Singapore : Oxford University Press, 1990), 61.

44. Howard M. Federspiel, "Áspects of Islamic Religious Law in Twentieth Century Indonesia", class paper; (McG̣ill University, 1962), 1.

45. Ali "The Position of Islamic Law", in Islam and Socicty in Southeast Asia, ed. Abdullah, 187. See also Aqib Suminto, "İslam in. Indonesia : Syncretism, Decontaminalion and Reform", in Mizan, 6 vol. II (1985), 27.

46. Amir Syarifuddin, Pelaksanaan Hukum Kewarisan Islam dalam Lingkungan Adat Minangkabau, (Jakarta' : Gunung Agung, 1984), 133.

47. Ibid. 
Islamicláw. The walis (Islamic saints) tried to change these habits.48

It was Sunan Kalijaga who, according to some scholars, introduced a certain method; he converted them to Islam wisely, not destroying their institutions to avoid hurting the society. He allowed them to come together in the deceased house in the same time as before. However, he changed the content of the institution. He asked them, in this ceremony, to say La Ilaha Illa Allah (There is no God but Allah) in certain number of times; reciting parts of the Qur'an, - and say prayers for the deceased, which came to be known as tahlilan in latertimes. ${ }^{49}$ They came together and, unconsciously, they were Islamized in the ceremony, because they, especially the younger generation, thought that they had to come to the ceremony when someone died because it was the social obligation. ${ }^{50}$ Unfortunately, Indonesian Muslims who do not understand the history and Kalijaga's strategies consider tahlilan as bid'ah (a poor-innovation inreligious competency). Islamic law, in this regard, faced and Islamized the local practices, but it has been considered as bid'ah by many modemist scholars. .

Clashes between Islamic law and local practices exploded when Kaum Padri (Padri's movement of Islamic purification in Minangkabau) tried to bring adator local practices to Islamic law. Tedjaningsih Jaylani says :

"The' conflict between adat law and shari'ah came to a serious stage in the first quarter of the nineteenth century when the number of Indonesians who had performed pilgrimage not only performed the pilgrimage rites but also took the opportunity to study Islam from the original sources. They stayed in the holy land for a considerable time and there was continuous influence on the progress of Indonesian Muslims in their homeland through the pilgrims who came every year to Mekkah. These hadjis (Ar. Hajj) became religious teachers when they had come back to Indonesia, and thus Islam penetrated more deeply into the Indonesian community. The influence of the Jawa colony culminated in the Padri movement. Led by Haji Miskin of Minangkabau who came back from Makkah inspired by Wahhabi ideas, the movement became stronger and stronger. The matriachal system and the supersitions in the adat of Minangkabau became targets of the bitter criticism ; everything which was against the teachings of Islam was to be abolished. ${ }^{51 "}$

\section{In other words, Islamic Reformation} faced Kaum Adat (customary leaders). Stemming from conflicts in religious practices, the tensions became a political struggle..$^{52}$

The Dutch intervened by defending adat (local practices) and their efforts at discrediting İslamic law could be seen in enacting nineteen regions of adat law :

48. Departemen Agama RI, Ensiklopedi Islam di Indonesia, ed. Harun Nasution et. al.,; (Jakarta : Departemen Agáma RI, 1987/1988), III : 885.

49. Zamakhsjari Dhofier says that : "thalil, fraying in slametan and talgin are symbols of santri's leadership over abangan". Zamakhsjari Dhofier, "Santri Abagnan dalam Kehidupan Orang Jawa : Teropong dari Pesantren", in Agama dan Tantangan Zaman : Pilihan Artikel Prisma 1975-1984, ed. M. Dawam Rahardjo (Jakarta : LP3ES, 1985), '193. ' ·

50. Ibid.

51.Tedjaningsih Jaylani, "Islamic Marriage Law in Indonesia", M.A. thesis, McGill University, 1959, 40-41.

52. Departemen Agama, Ensiklopedia Islam, III : 7.16-717. 
1. Aceh (excluding the Gayo - and Alaslands); 2. The Gayo-, Alas-, and Bataklands; 3. The Minangkabau territory; 4. South Sumatra; 5. The Malayterritory, that is, the east coast of Sumatra (excluding the Batak area) together with the RiauLingga archipelago, of which the Malayan peninsula could be regarded as the British moiety); 6. Bangka and Bitung; 7. Borneo excluding Serawak North Borneo; 8 . The Minahasa; 9. The territory of Gorontalo; 10. South Celebes, together with the Buginese coast of the island; 11 . The Toraja territory; 12. The Temate archipelago; 13. Ambon and Moluccas (Seram, Buru, etc); 14. Dutch New Guinea; 15. Dutch Timor with its archipelago; 16. Bali and Lómbok; 17. Central and East Java, with Madura; 18. The Central Javanese Principalities; 19. West Java (Pasundan)..$^{53}$

When Indonesia got its independënce from the Dutch, Indonesian scholars, as said before, focused their orientation, among others, on abolishing the reception theory. which had supported the local practices. Whille they did their best in this aspect, unfortunately they did not succeed one hundred per cent. Prostitution, gambling, drinking, murdering, robbing, and rape are some examples of problems islamic law faces in an independent Indonesia. These problems actually challenge not only Islamic jurisprudence, but also most of Divine law.

Islamiclaw works hand in hand with the. Indonesian Govemment in order to solve these problems. It can be discemed in the cooperation between the govemment and the Council of Indonesian 'Ulama'. Indeed, the latter frequently gave fatwa to the former. Indonesian scholars call this mutual understanding as bulan madu (honeymoon) between the two. The Govermment of Indonesia has a similar interest in solving these problems.

\section{Prognosis}

Islamic law in Indonesia has always interacted with the social realities surrounding it. It has faced a variety of challenges ranging from the very serious to the insignificant. Three regenerations that Islamic Law will be facing in Indonesia will be given here.

It appears that there will be little change in Islamic Law in Indonesia up to the year 2000, because the state is not an Islamic State, and local practices are sometime supported by the govemment. Further intellectual reformation as tehe most important aspect is still too undeveloped to confront the problems. The case will probably be almost the same in all respects in the year 2020, except that the intellectual foundations of Islamic Law will have solidified, because an expanded consciousness of the importance of intellectual restoration. It is hoped that some Doctors in Islamic Law will be produced in this period either by IAINs or by some non-Indonesian universities in order to strengthen the postgraduate faculties of the IAINs: Certainly, the intellectual foundations of Iślamic Law will be much stronger in the year 2050 because there will be an increasing number of doctors graduate in Islamic law. But the

53. Van Vollenhoven, Van Vollenhoven on Adal Law, tr. J.F. Holleman et. al., ed.J.F. Holleman (The Hague: Martinus Nijhoff, 1981), 44. See also, Simorangkir and Sastropranoto, Peladjaran Hukum, 70. 
problems that Islamic Law will be facing are unpredictable. Political changes, the local practices that have always challenged Islamic Law will be replaced by 'intemational practices' because of the technological expansion that will be bringing more and more non-Islam practices. Questions will continue regarding the productivity of Islamic law scholars.

\section{Bibliography}

Abduliah, Abdul Rahman Haji. Pemikiran Umat Islam di Nusantara : Sejarah dan Perkembangannya Hingga Abad ke-19. Kuala Lumpur : Dewan Bahasa dan Pustaka, 1990.

Alfian Ibrahim. Perang di Jalan Allah. Jakarta : Pustaka Sinar Harapan, 1987.

Ali, Muharnmad Daud. "The Position of Islamic Law in the Indonesian Legal System". Islam and Society in Southeast Asia, ed. Taufiq Abdullah and Sharon Shiddique : 187-205. Kuala Lumpur : Institute of Southeast Asian Studies, 1986.

Ali, A. Mukti. Beberapa Persoalan Agama Dewasa ini. Jakarta : Rajawali, 1987.

Anshari, Endang Shaifuddin. The Jakarta Char'ter 1945 : the Struggle for an Islamic Constitution in Indonesia. Kuala Lumpur :Muslim Youth Movement of Malaysia, 1970 .

Basyir, Ahmad Azhar. "Posisi Hukum Islam dalam Pembinaan Hukum Nasional". In Media Dakwah 119 (Jumadil Akhir 1411/Januari 1991) : 40-51.

Basuni, H. Ahmad. Nur Islam di Kalimantan Selatan (Sejarah Masuknya Islam di Kalimantan). Surabaya : Bina IImu, 1986.

Daudy, Ahmad. "Tinjauan atas "Fath al-Mubin" karya Syaikh Nuruddin ar-Raniri". Warisan Intellektual Indonesia : Telaah atas Karya-karya Klasik, ed.' Ahmad Rifa'i Hasan, 21-23. Bandung : Mizan, 1987.

Dhofier, Zamakhsjari. "Santri-Abangan Kehidupan Orang Jawa: Teropong dari

- Pesäntren". Agama dan Tantangan Zaman Pilihan Artikel Prisma 19751984, 177-194. Jakarta : LP3ES, 1984.

Djaja, Tamar. Riwayat Hidup A. Hasan. Jakarta : Mutiara, 1981.

Dwyer, Daisy Hilse. Law and Islam in the Middle East. New York : Bergin \& Garvey'Publisher, 1990.

Federspiel, Howard M. "Aspects of Islamic Religious Law in Twentieth Century Indonesia". Class paper, Islamic Studies McGill University, 1962.

Federspiel, Howard M..Persatuan Islam : Islamic Reform in Twentieth Century in. Indonesia: New York : Comell University, 1970.

Gadjahnata, K.H.O. and Sri-Edi Swasono. Ed. Masuk dan Berkembangnya Islàm di Sumatera Selatan. Jakarta : UIP, 1986.

Gani, M.A. Citra Dasar dan Pola Perjuangan Syarikat Islam. Jakarta : Bulan Bintang, 1984.

Hafiduddin, Didin. "Tinjauan'atas. "Tafsir alMunir" karya Imam Muhammad. Nawawi Tanara": Warisan Intellektual Islam Indonesia : Telaah atas Karyakarya Klasik, ed. Ahmad Rifa'i Hasan, 39-56. Bandung : Mizan; 1987.

Hasan, Rila'i Ahmad. Ed. Warisan Intellektual Islam'di Indonesia: Telaah Atas Karyakarya Klasik. Bandung : Mizan, 1990.

Hirzin, M. Habib. "Agama dan Ilmu dalam

Pesantren". Pesantren dan Pembaharuan, ed. M. Dawam Rahardjo, 77-94. Jakarta :LP3ES, 1974.

Hooker, M.B. "Muhammadan Law and Islamic Law". Islam in Southeast Asia, ed. M.B. Hooker, 160-182. Leiden : E.J. Brill, 1983.

Jamil,' Fathurahman. "Upayä Pembaharuan 
Hukum Islam di Indonesia". In Mimbar Agama \& Budaya. 6 Desember 1984 : 16-24.

Jaylani, Tedjaningsih. "Islamic Marriage Law in Indonesia". M.A. Thesis, McGill University, 1959.

Kartodirdjo; Sartono. Protest Movement in Rural Java: A Study of Agrarian Unrest in the Nineeth Century and Early Twentieth Centuries. Singapore : Oxford University. 1973.

Kuntowidjojo. Paradigma Islam : Sebuah Interpretasi untuk Aksi (Bandung : MIzan, 1990).

Lembaga Research Pesaritren Luhur Jawa Timur. Sejarah dan Da'wah Islamiyah Sunan Giri. Gresik : P3SG, 1973.

Lubis, Mochtar. Indonesia. Land under the Rainbow.Singapore:Oxford University Press, 1990.

Maarif, áhmad Syafii. Islam dàn Masalàh Kenegaraan : Studi tentang Percaluran dalam Konstituante, Jakarta : LP3ES, 1985.

Maarif, Ahmad Syafii. Islam dan Politik di . Indonesia pada Masa Demokrasi Terpimpin (1959-1965). Yogyakarta : Sunan Kalijaga Press, 1988.

Mahjuddin. Masailul Fiqhiyah : Berbagai Kasus yang Dihadapi Hukum Islam Masa Kini. Jakarta : Kalam Mulia. 1990.

Masagung, Yayasan. Búku Islam Sejak Tahùn 1945. Jakarta : Pusat Informasi Islàm, 1985.

Nakamura, Hisako. Divorce in Java. Yogyakarta : Gajah Mada University Press, 1983.

Noch, H. Zaini 'Ahmad and H. Abdul Basit

-Adnan. Sejarah Singkat Pengadilan Agama Islam di Indonesia. Surabaya : Bina Ilmu, 1983.

Noer, Deliạr. Partai Islam di Pentas Nasional. Jakarta : Grafitipress, 1987.

Noer, Deliar. The Modernist Movement in Indonesia 1900-1942. Singapore-Kuala Lumpur: OxfordUniversity Press, 1973.
Quzwin, M. Chatib. "Syaikh 'Abd al-Shamad al-Palimbani : Suatu Studi Mengenai 'Perkembangan' Islam di Palembang dalam Abad ke-18 Masehi". Masuk dan Berkembangñya Islam di Sumatera Selatan. ed. K.H.O. Gadjahnata and SriEdiSwasono, 174-190.Jakarta:Penerbit Universitas Indonesia, 1986.

Rahadjo, Dhwam. Ed. Pesantren dan Pembaharuan Jakarta : LP3ES, 1974.

Rasyaụ, Aminuddin and Baihaqi A.K. Sejarah Pendidikan Islam di Indonesia. Jakarta: .Departemen Agama: 1986 .

RI, Departemen Agama. Ensiklopedi-Islam di Indonesia, ed." Harun Nasution et. al. Jakarta : Departemen Agama RI, 1987/ i988.

Ricklefs,M.C. 'A History of Modern Indonesia. Bloomington: IndianaUniversity Press, 1981.

Rusin, M. Rusni. "Hukum Islam" dalam Tata Hukum Indonesia". In Studi Islamica 8 (Juli - September; 1987 : 37-41).

Saidi, Ridwan. Pemuda Islam dalam Dinamika Politik Bangsa 1925-1984 (Jakarta : Rajawali, 1984).

Shalabi, Mustafa Muhammad. Al-Madkhal bi al-Ta'rif bi al-Figh al-Islami wa qawa'id al-Milkiyyat wa al-'Uqud fih. Cairo : Dar al-Ta'rif, 1960.

Simorangkir, J.C.T. and "Woerjono Sastropranoto. Peladjaran Hukum Indonesia Jakarta : Gunungágung, 1958.

Simuh "Aspck Mistik Islam Kejawen dalam "Wirid Hidayat Jati". . Warisan Intellektual Islam Indonesia': Telaah atas karya-karya Klasik, ed. Ahmad 'Rifai'i Hasan, 59-79. Bandung : Mízan, 1987."

Siregar, Bismar. Islam \& Hukum. Jakarta : Pustakakarya Grafikatama;"1980.

Suminto, Aqib. "Islam in Indonesia : Syncretism, Decontamination, "and Reform". In Mizan, 6 (Vol. II, 1985) : 27-31.

Suny, Ismail. "Islam as A System of Law in 
Indonesia", in Pembaharuan, Hukum di

- Indonesia in Memoriam Prof. Mr. Dr. Hazairin.'Jakarta : Penerbit Universitas 'Indonesia, 1981 : 16-21.

Syarifuddin, Amir. Pelaksanaan Hukum Kewarisan Islam dalam Lingkungan Adat Minangkabau (Jakarta : Gunung Agung, 1986).

Tempo No. 38 Tahun XXI - 16 Nopember, 1991.

Thalib, Sajuti. "Reception in Complexu, Theori Receptie dan Receptie A Contrario".
Pembaharuan Hukum Islam di Indonesia in Mernoriam Prof. Mr. Dr. Hazairin, 44-45. Jakarta : UI Press, 1981.

Vollenhoven, Van. Van Vollenhoven on Indonesian Adat Law, tr. J.F. Holleman, Richel Kalis, and Kenneth Madduck, ed.J.F. Holleman. The Hague: Martinus Nijhoff, 1981 .

Wahidin, Samsul and Abdurrahman, Perkembangan Ringkas Hukum Islam di Indonesia Jakarta : Akademika Pressindo, I984. 